Journal of Social Sciences 8 (2): 202-206, 2012

ISSN 1549-3652

(C) 2012 Science Publications

\title{
Creating New Spaces for Learning: Fostering Experiential and Service Learning, Journeys through the African American Past
}

\author{
Dolapo Adeniji-Neill \\ Department of Curriculun and Instruction, Ruth S. Ammon School of Education, \\ Adelphi University, 1 South Ave., Garden City, New York, 11530, USA
}

\begin{abstract}
Problem statement: Experiential education and service learning are interchangeable. They are defined as an approach to education that implicitly trusts the learner's ability to learn through experience, rather than a movement for change that seeks to challenge mainstream education. While literature, research, communities and schools recognize the importnce of experiential education, controversies exit as to their efficacies in learning processes. Approach: Experiential education and service learning are complimentary to formal education. They create communities and enables learners to interact with the world beyond the classroom. It was upon such community building and the belief that students would gain useful knowledge that would be life fulfilling that the "Project Period" was built. It started in a small community of a 300 -student 9-12 secondary school in a village in New Hampshire, United States. Results: The projects were designed to allow students to engage with community, foster curiosity, ignite critical thoughts and enable students to see the world in multi-faceted dimensions. Conclusion: Studies on experiential learning tend to focus on environmental education and outdoor programs. As indicated, experiential education can be a part of K-College curricula and can focus on the big philosophical question, such as "How do historical periods affect the past, the present and the future"?
\end{abstract}

Key words:Experiential learning, immersion field trips, phenomenological research, underground railroad, slavery

\section{INTRODUCTION}

Higgins (2009) notes experiential education and service learning are generally used interchangeably and he defines them as an approach to education that implicitly trusts the learner's ability to learn through experience, rather than a movement for change that seeks to challenge mainstream education. Experiential education and service learning are complimentary to formal education. They are powerful tools that leads to fundamental changes in the ways students learn and teachers teach. To (Eyler, 2009), experiential education necessarily takes students into the community, helps them to bridge classroom study and life in the world and transform inert knowledge into knowledge-in-use. She further states that it anchors on a process that enables the learner to interact with the world and integrates new learning into old constructs. It creates communities of learning that encourage cooperation and reciprocity among students, improves learning and is particularly well suited to field-based projects.
It was in such a community that the "Project Period", the purpose of this study was built. It started in a small community of a 300-student 9-12 sec ary school in a village in New Hampshire. The projects were designed to allow students to engage with community, foster curiosity, ignite critical thought and enable students to see the world in a different way: a multi-faceted world, rather than one that is only black or white. These ideas were not new; they were only built upon. Rone (2008) asserts that the ideas and theories behind experiential education are as old as human communities; further, informal learning embedded within the processes of enculturation ensured human survival because it encouraged interactive encounters with the social world. Formal explanations of experiential education can be understood through Freire $(2000 ; 1998)$ educational theories in the Pedagogy of the American educational philosopher, Dewey (1998), in his book, Experience and Education, viewed experience as the main criteria in education; and continuity and interaction were the two fundamental influences in determining the quality of 
experience and its implications for education. For Dewey, an experience elicits curiosity, strengthens initiatives and sets up desires that are sufficiently intense to carry a person over difficulties in the future; it is deemed positively educative. Dewey advocates for education that encapsulates the lived experiences of the learner. Wyk (2008), asserts, that meaningful experiences for students have to involve collective and shared experience that enhances personal and intuitive experience.

Theoretical guidelines: This research is grounded in the theoretical tradition of phenomenological inquiry. According to (Patton, 1990) phenomenological inquiry focuses on the meaning, the structure and the essence of lived experiences of the researcher and the group involved in the experiences.

From a phenomenological point of view, we are less interested in the factual status of particular instances whether something happened, how often it tends to happen, or how the occurrence of an experience is related to the prevalence of other conditions or events. For example, phenomenology does not ask, 'How do these children learn this particular material?' but it asks, 'What is the nature or essence of the experience of learning (so that I can now better understand what this particular learning experience is like for these children)' (Van Manen, 1990; Patton, 1990).

\section{MATERIALS AND METHODS}

The project period: This study deals with the service learning and immersion field trip nature of three of the projects (Dewey, 1998; Scarce, 1997), African American Heritage in New England that I was the faculty sponsor for 6 years. The project involved over 60 students, 9-12 graders. We named the project, Follow the Drinking Gourd: a reference to the north stars or the Big Dipper star formation that guided the runaway slaves travelling north to freedom in the northern states and Canada. While students and faculty sponsors were on the road for a week, like the enslaved on the Underground Rail Road, we depended mainly on the hospitality of "strangers" for our meals and lodging. We slept on church basement cement floors, in army barracks, college student centers, a museum as well as many fine homes of the school's friends who heard about the journeys we were embarking on. Following is a folk song that was believed to have been sung by the escaping slaves as a voice map to help them get to freedom.

The American folksong follow the drinking gourd was first published in 1928 by H.P. Parks who reported hearing the songs from the African American community in the mountains in Hot Springs, North Carolina, U.S.A. (http://www.followthedrinkinggourd.org/) (Fig. 1).

The projects: Follow the drinking gourd (Fig. 1): Trip year 1 follow the drinking gourd: African American Heritage in New England: $\mathrm{N}=12$, including the researcher and her spouse, Albert R. Neill. This project like the following two combined experiential learning approach with community service. The period was the week following the school's usual Spring Break that in these cases are the last week of March. Students could chose from a wide array of projects then work together in a small group setting with members on a hands-on project outside the structure of the normal classroom (Table 1).

\begin{tabular}{|c|c|c|}
\hline Day & Time & Description \\
\hline \multirow[t]{6}{*}{ Day 1} & 11:30 a.m. & Depart from school campus \\
\hline & 1:50 p.m. & $\begin{array}{l}\text { Departure from Manchester airport, } \\
\text { New Hampshire (MHT) on southwest airlines }\end{array}$ \\
\hline & 3:10 p.m. & Arrival at Baltimore/Washington airport (BMI) \\
\hline & 5:30 p.m. & Dinner at Maran's residence (school parents) \\
\hline & 7:10 p.m. & Nighttime tour of the nation's capital \\
\hline & 11:00 p.m. & Lights out \\
\hline \multirow[t]{8}{*}{ Day 2} & 9:30 a.m. & Depart for the museum \\
\hline & 11:00 a.m. & $\begin{array}{l}\text { Tour of the Anacostia museum and center } \\
\text { for African American History and culture }\end{array}$ \\
\hline & 12:00 noon & Lunch \\
\hline & 2:00 p.m. & $\begin{array}{l}\text { Frederick Douglass homestead National } \\
\text { Historic site (visitors center and home) }\end{array}$ \\
\hline & 4:00 p.m. & Journal writing by students \\
\hline & 6:00 p.m. & Dinner at Fisakas Ethiopian restaurant \\
\hline & 8:00 p.m. & Watch La Amistad movie \\
\hline & 11:00 p.m. & Discussion and lights out \\
\hline \multirow[t]{5}{*}{ Day 3} & 10:00 a.m. & Howard University seminar and lunch \\
\hline & 1:00 p.m. & $\begin{array}{l}\text { Briefing by Chris Cloud, executive director } \\
\text { and captain bill pinckney, Amistad America } \\
\text { Tour of howard university }\end{array}$ \\
\hline & 5:30 p.m. & Dinner and movie at mazza galleria \\
\hline & 10:00 p.m. & Journal writing by students \\
\hline & 11:00 p.m. & Lights out \\
\hline \multirow[t]{8}{*}{ Day 4} & 8:30 a.m. & $\begin{array}{l}\text { Assist setting up for arrival of La amistad, } \\
\text { selling tickets, }\end{array}$ \\
\hline & 11:00 a.m. & Welcoming flotilla, performance by the \\
\hline & & U.S. Navy band and ceremonial color guard. \\
\hline & & Procession and interfaith service \\
\hline & 3:00 p.m. & $\begin{array}{l}\text { Public tours of La amistad } \\
\text { Assist and serve as guides }\end{array}$ \\
\hline & 7:00 p.m. & Supper at Maran's home \\
\hline & 8:00 p.m. & Ford's Theatre, The hot mikado \\
\hline & 11:30 p.m. & Lights out \\
\hline \multirow[t]{6}{*}{ Day 5} & $8: 30$ a.m. & Gangplank marina \\
\hline & & Assist in setting up for the day \\
\hline & 9:00 a.m. to & Educational exhibits and public tours \\
\hline & 6:00 p.m. & Assist as guides, ticket sales, \\
\hline & & Crowd control, merchandise sales, \\
\hline & 11:00 p.m. & Lights out \\
\hline \multirow[t]{6}{*}{ Day 6} & 7:00 a.m. & Breakfast and packing \\
\hline & 8:00 a.m. & Depart for BMI \\
\hline & 10:00 a.m. & Departure on southwest airlines \\
\hline & $11: 15$ a.m. & Expected time of arrival at \\
\hline & & Manchester, new hampshire \\
\hline & $12: 30$ p.m. & Return to school campus \\
\hline
\end{tabular}




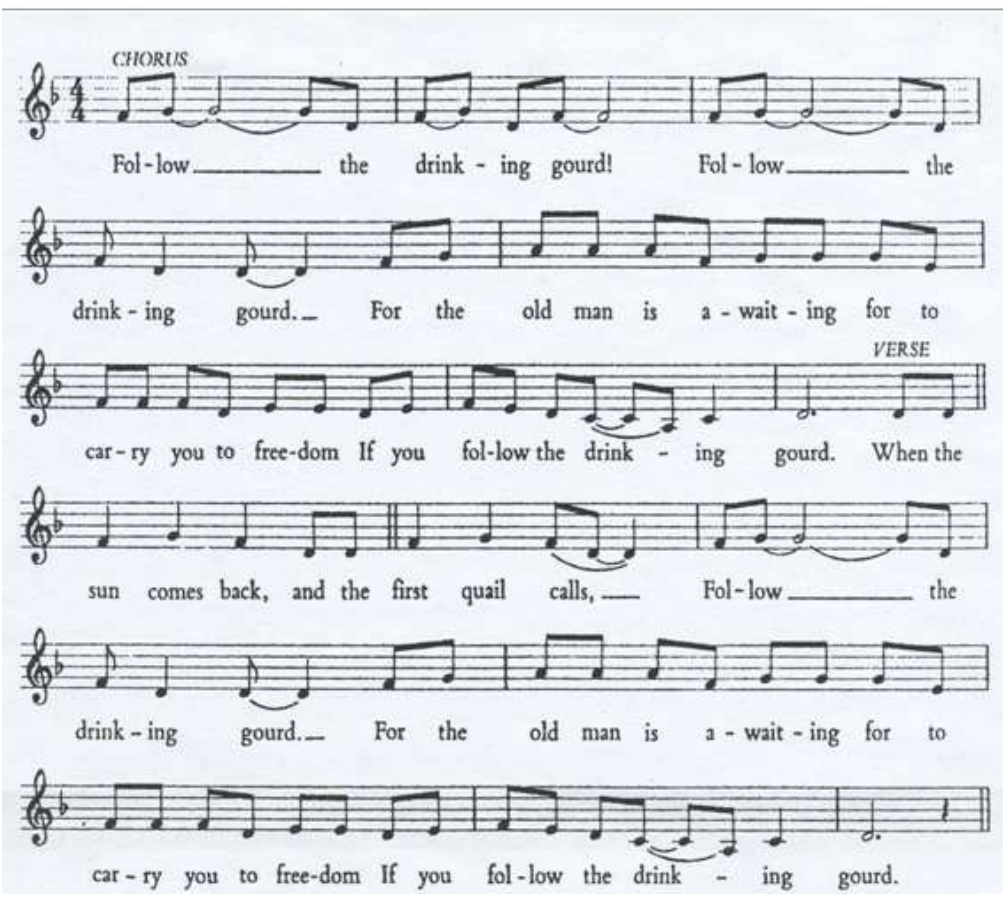

Fig. 1: Music sheet for the song: "Follow the Drinking Gourd" A song attributed to the enslaved on Underground Rail Road

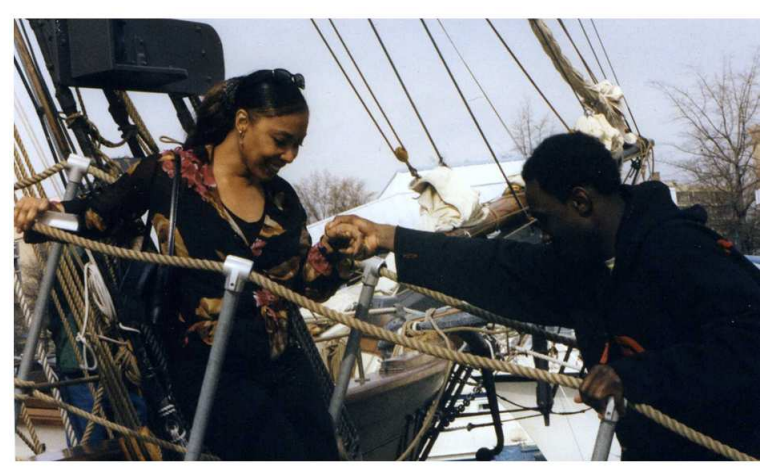

A student docent helping a visitor disembark from the ship, La Amistad

Fig. 2: A student docent helped an Amistad visitor disembark from the reconstructed slave ship

The school is an independent boarding school in a small New England village in the United States. Community service is considered an important part of all students' experiences. The core belief: community service or experiential learning holds the same level of importance as any other academic requirement. Project Number 1, documented here focused on the African American heritage of New England. Under the auspices of the Museum of African American History and the National Park Service on Beacon
Hill, Boston Massachusetts, the Charlestown Navy Yard and the Lowell Historical Mills complex, the students, a faculty member and the researcher worked with the National Park Rangers and Museum curators to create a digital photo record of selected artifacts. The materials were to be later edited and made accessible on the Museum and National Park websites. During students work-stay at the project sites they ventured into town as well as visited the Lowell Mills Complex where women and children worked and lived in the United States during the 1800's.

Before I proceed any further I must note that the success of any extended field-trip/service learning experience is hinged on careful planning and weeks, if not months, of collaboration and preparation with host destinations. Below is an example of a daily itinerary:

Trip year 2 follow the drinking gourd: The Amistad Slave Ship in Washington, D.C: $N=13$. This fieldtrip-service learning focused on African American heritage with a visit to Washington, D.C. where the students toured the Anacostia African-American Museum of the Smithsonian, the Fredrick Douglas home site and Howard University where we had discussions with faculty and Captain Pinkney of La Amistad on the subject of "How far we have come since the Amistad." The next day we greeted the arrival 
of the replica of the freedom schooner, La Amistad, which visited the nation's capital for the Cherry Blossom Festival and we as a group spent two days as docents and guides as well as selling tickets and merchandise for Amistad America (see Fig. 2).

Trip year 3 follow the drinking gourd: Slavery and Freedom in New England-The Amistad trials of 1839 and Mystic Seaport: $N=13$. This trip began at the Connecticut old state house courtroom in Hartford where the actual Amistad Slave Trials took place; students "became" members of the General Assembly and enacted the Amistad Slave Trials; here they found themselves grappling with the legal and social implications and consequences of slavery. And it was in the same chamber in 1833 that Andrew Judson persuaded the legislature to pass the infamous "Black Law." This made it virtually impossible to educate Black children in Connecticut, U.S.A. We later drove to Boston to tour the Black Heritage Trail, where we explored the history of the 19th century free Black community on the north slope of Beacon Hill. We visited Roxbury Preparatory Charter School where we talked to younger Black students about life in a boarding college preparatory school that they might be interested in attending later. We finally travelled to Mystic Seaport where once again students worked on getting the Amistad ready for another voyage.

\section{RESULTS AND DISCUSSION}

The foci of this study were: Service Learning on board the newly re-created slave ship, the Amistad at a port of call in Washington, DC. and archiving priceless artifacts at the museum of African American History, on Beacon Hill, Boston. Students also worked at tasks required by the organizations; they learned first hand from museum curators' lectures, watched the building of the Amistad at mystic seaport, Connecticut. They learned about the middle passage, the triangular trade routes of slavery to the Americas and participated in the reenactment of the Amistad Trials of 1839-1840, in the courtroom at Hartford, Connecticut, where the only slave trials in the United States resulted in the enslaved winning the law suit and granted the right and the freedom to return to Africa. They witnessed the site where Crispus Attucks, the first man to lay his life down at the rebellion against British occupation that is now known as the Boston Massacre of 1770 . History came alive for the students with the sights and sounds of real event places in the middle of the night or broad daylight with experienced docents. They sat in on lectures and worked on archiving at the United States' first one room school house built to house Black pupils in 1835, the Abel Smith School. Here, students learned of the plight of students unlike themselves who were denied education in schools in their neighborhood because of the color of their skin. We traversed the narrow alleyways of Beacon Hill, home to a thriving Black community from the mid 1700 's to the 19th century; and a place where those who had escaped from slavery in the South were chased and hunted down only to be returned to slavery due to the Fugitive Slavery Act of 1793, 1850. These laws allowed southern white slave owners to pursue runaways into northern territories.

Through students' photo artifacts analyses and anecdotes from their journals I seek to bring to light the experience of immersion field trip and service learning. And so the crux of this study is anchored on the nature or essence of experiential/service learning/immersion field trips and the particular experiences of the students involved.

\section{CONCLUSION}

Most studies on experiential learning focus mainly on environmental education and outdoor programs. As indicated, experiential education can be a part of kcollege education curricula and can focus on the knowledge of the big philosophical questions such as "How do historical periods affect the past, the present and the future?" "What role does slavery play in our democracy?" "How can service learning build character and foster understanding of those who are outside our social, ethnic and racial group?" It was in pursuit of these philosophical questions that we embarked on the three journeys above. Were these questions answered unequivocally in the minds of all the students and faculty involved? Most probably not; but the seeds have been planted and more questions raised. These experiences were more or less about the journey and about stretching and gaining knowledge that may not otherwise be available to us in it is entirety if we had remained stationary in our classrooms. As a faculty sponsor and social science educator, the trips have changed how I approach my lessons. I have come to solidify my beliefs that educations must have ways and means of relating to reality; otherwise, we run the risk of losing many students' interests. When all is said and done how do we access our experiences? Accountability is a good thing but there are many things. In all the projects we asked the students to write journals, put their feelings into words and to rate their experiences in categories such as:

\section{- Travel convenience}


- Camaraderie with fellow travelers, other students and getting along with peers

- Project experiences

- Learning

- Satisfaction with own contributions

- Forming new constructs/new discoveries

From the journals, surveys and talking to student participants, we found that their experiences were rated well over $90 \%$ across the board, on how meaningful the experiences were, how much knowledge they had gained and the value of social and interpersonal relationships between them, the people and places we worked in and visited.

\section{REFERENCES}

Dewey, J., 1998. Experience and Education. 60th Edn., Kappa Delta Pi, West Lafayette, India, ISBN-10: 0684838281, pp: 181.

Eyler, J., 2009. The power of experiential education. Liberal Educ., 95: 24-31.

Freire, P., 1998. The Paulo Freire Reader. 1st Edn., Continuum, New York, ISBN-10: 0826412750, pp: 291.
Freire, P., 2000. Pedagogy of the Oppressed. 30th Edn., Continuum International Publishing Group, New York, ISBN: 0826412769, pp: 183.

Higgins, P., 2009. Into the big wide world: Sustainable experiential education for the 21 st century. J. Exp. Educ., 32: 44-60.

Manen, M.V., 1990. Researching Lived Experience: Human Science for an Action Sensitive Pedagogy. 1st Edn., State University of New York Press, New York, ISBN-10: 0791404269, pp: 202.

Patton, M.Q., 1990. Qualitative Evaluation and Research Methods. 2nd Edn., Sage Publications, Thousand Oaks, CA., ISBN-10: 0761919716, pp: 532.

Rone, T.R., 2008. Culture from the outside in and the inside out: Experiential education and the continuum of theory, practice and policy. College Teach., 56: 237-245.

Scarce, R., 1997. Field trips as short-term experiential education. Teach. Sociol., 25: 219-226.

Wyk, VB., 2008. Learning and an African lifeworld in (higher) education. INDILINGA, 7: 171-181. 